\title{
Impact of Covid-19 on Interest Rates
}

\author{
Lo Yi-Wei \\ Department of Economics, National Cheng Kung University, Taiwan \\ Received: August 4, 2020 \\ Received in Revised: August 13, 2020 \\ Accepted: August 15, 2020
}

\begin{abstract}
The global economy is experiencing a crisis due to the Covid-19 pandemic, the stock market index has collapsed. The exchange rate against the USA dollar weakened this was due to the large number of foreign investors leaving the financial market, the stock market plummeted. The banking sector can carry out an economic stimulus given restructuring authority for all credit or financing without requiring restrictions on the credit ceiling or type of debtor, especially debtors for MSMEs and informal workers. The economic stimulus that needs to be maximized is prundential monetary and macro policies through lowering interest rates and maintaining stability in the exchange rate. Budget relocation is also enforced to maintain the availability of basic foodstuffs for the community, which has increased due to panic buying or market panic. Also providing assistance to increase people's purchasing power.
\end{abstract}

Keywords: Interest Rates, Inflation, Export, Import

\section{Introduction}

As that education is the main thing to achieve a satisfying and dignified life. Education is one of the fundamental things to form a broader human capability that is at the core meaning of development. Education plays a key role in shaping the ability of a developing country to absorb modern technology and to develop capacities for sustainable growth and development. Education contributing significantly to economic development has become an axiomatic truth. Various academic studies and empirical research have proven its validity. Education is not only incubating quality human resources, possessing knowledge and skills and mastering technology, but also can foster a business climate that is healthy and conducive to economic growth. Therefore, investing in education is not only beneficial for individuals, but also for the business community and the general public. Educational attainment at all levels and circles will undoubtedly increase people's income and productivity. Education is the way to progress and achieve social and economic welfare.

Health is part of politics because health care is a public service that should not only be used as a vehicle for regional heads. The current concept of health in the form of health development in the form of individual health services, rather than broad community health services. For example, data on the number of Covid-19 sufferers, the number of poor people, the ratio of the population to the number of health facilities and basic service procedures and referrals should be provided to the public in a transparent manner.

The number of patients infected with the corona virus or covid 19 in the world continues to increase until April 21, 2020, it has been recorded that there are 7,135 positive cases, 616 people died and 842 people recovered. The Covid 19 pandemic has spread across the world. The impact 
that is currently being felt is on various sectors, such as the health, education, social, economic and religious activities in the community. The public is starting to feel the impact on these sectors.

The government has declared the corona virus pandemic a non-natural national disaster. The determination of the disaster status is in line with the increasing number of positive corona virus patients which is increasing day by day. As a non-natural disaster, awareness of all parties is needed to take a role in dealing with this corona virus disaster.

When viewed from the distribution of this pandemic, it is almost evenly distributed throughout the world. The government, as the party most responsible for the health of its people, has never stopped providing information, education and motivation to deal with this corona pandemic so that it does not spread and worsen the situation.

\section{World Economy}

The global economic crisis due to the Corona virus outbreak or the Covid-19 pandei, logistics, tourism and trade activities are sectors that have had a major impact from the Corona Virus outbreak (Rosenbaum, 2020; McKibbin \& Fernando, 2020). This is due to the prohibition of a number of governments from traveling abroad and the closure of several tourism sectors as a result of the lack of foreign tourists.

The impact of the trade sector, particularly exports and imports, raw materials and capital goods. Production decreases, goods are scarce and the price of goods continues to increase, causing inflation (Baldwin et al, 2020; Bonoli, 2010; Nicola et al, 2020; Ramelli \& Wagner, 2020; Clemens \& Veuger, 2020). An increase in the price of goods accompanied by a decrease in income is a fatal condition for people's purchasing power. Some of the raw materials for industry in the world are still supplied from China, which is experiencing production constraints due to quarantine in a number of regions to stem the Covid-19 pandemic.

Currently the global economy is experiencing a crisis due to the Covid-19 pandemic, the stock market stock index has collapsed. The exchange rate against US dollars weakened this was due to the large number of foreign investors leaving the financial market, the stock market plummeting, affecting the domestic economy. The strengthening of the US dollar occurred due to panic in the global market due to Covid-19 and the volatility in the oil market. It is possible that the exchange rate will continue to weaken against the SA dollar exchange rate.

To encourage economic growth to continue in the midst of the economic crisis due to the Covid19 outbreak, the government has issued a stimulus which is summarized into 3 stimuli, namely fiscal, non-fiscal and economic sector stimuli (Douglas et al, 2020). The three stimuli are related to the needs of the community in the fields of business, business, taxes and so on. Many finance ministers across the world has coordinated with a number of institutions such as the Financial Services Authority, the Deposit Insurance Corporation and the Financial System Stability Committee.

Leaders have provided and announced a credit relaxation or concession for small businesses and informal workers who are running installments. This policy is easier than the tax amnesty policy that the government has implemented for citizens. 
This stimulus regulation was previously released by the Financial Services Authority on March 9, 2020 through the Financial Services Authority Regulation concerning the National Economic Stimulus as a Countersyclical Policy on the impact of Coronavirus Disease.

With this issuance, a stimulus will be provided for the banking industry from March 132020 to March 31, 2021. Banks can be proactive in identifying debtors who are affected by the spread of Covid-19 and immediately implement the stimulus.

The banking sector can carry out an economic stimulus to be given restructuring authority for all credit or financing without requiring restrictions on the credit ceiling or type of debtor, particularly debtors for MSME actors and informal workers. The Financial Services Authority provides credit relaxation for MSMEs for credit values below 10 billion in minimizing the impact of the Covid-19 outbreak, both loans provided by banks and the non-bank financial industry.

Relaxation is given to formal workers such as a number of motorcycle taxi drivers including online motorcycle taxis, taxi drivers and fishermen who still have vehicle loans or work tools such as fishing boats. There will be a delay in installments or insurance for 1 year and a reduction in interest rates.

This condition is different from the economic crisis in 1998 where the many sector actually became a support when several banking sectors were liquidated. Meanwhile, at present, MSMEs are directly hit by the impact of the Covid-19 outbreak. This occurs due to a significant decrease in people's purchasing power, especially at the lowest level.

Under these conditions, all countries will relax in economic stimulus, relocate budgets to the health sector, food supply and people's purchasing power. Funding is diverted to procure epidemic control equipment and tools as well as to finance research that focuses on finding antivirus.

Budget relocation is also enforced to maintain the availability of basic foodstuffs for the community, which has increased due to panic buying or market panic. Also providing assistance to increase people's purchasing power to meet their daily needs. Funding stimulus in order to increase domestic production in the agricultural sector. In the current condition, the need for food for proper nutrition and nutrition such as vegetables and fruits has increased in demand. So far, government imports to meet demand for this commodity.

The economic stimulus that needs to be maximized is prundential monetary and macro policies through lowering interest rates and maintaining stability in the exchange rate. Limiting the spread of negative information and hoaxes is an important step to take in maintaining public trust and strengthening resilience which has implications for price stability and availability of public needs.

Maybe the corona virus outbreak or the Covid-19 pandemic has put us in a position that is not prime but in every crisis that follows there are always opportunities that follow. We are in a situation that is not easy. Keep thinking positive and optimistic as an effort to overcome the biggest enemy of society, namely fear and panic. 


\section{The covid-19 relationship in the world of economy is related to simple interest}

You made a shopping transaction on March 1, 2020 for 2 million, interest of $2 \%$ per month. Print invoices every March 20 (20 days), due April 5, 2020. You just paid a bill of 500 tahousand on April 1, 2020.

Interest per day $\quad=(2 \% \times 12$ months $): 365$ days $=0.0006575$

$$
=\text { USD } 2 \text { million } \times 0.0006575 \times 20 \text { days }=\text { USD. } 26,300
$$

Amount deducted on April 1-20 = USD 500 thousand $\times 0.0006575 \times 20$ days

$$
=\$ 6,575
$$

Interest rate March 21 - April $212020 \quad$ = USD 2 million x 0.0006575 x 31 days

$$
=\$ 40,765
$$

The total credit card debt that must be paid on the next bill is:

$$
\begin{aligned}
& =\text { USD } 1.5 \text { million + USD 26,300 + (USD 40,765 - USD 6,575) }=\text { USD. } \\
& 1,560,490
\end{aligned}
$$

\section{Covid-19's relationship in the public sector to interest is modest}

The Regent received a budget channel from the Governor of 25 million. Each budget for helping the community affected by the Covid-19 outbreak is given a weekly interest of $5 \%$. How much did the Governor invest in assisting the Regent?

Settlement:

Because $\mathrm{P}$ is not known, the formula is changed to find $\mathrm{P}$, namely $\mathrm{P}=\mathrm{L}$ (ixn)

$\mathrm{L}=$ amount of aid budget (25 million)

$\mathrm{i}=$ budget interest $(5 \%)$

$\mathrm{n}=$ number of time (7 days)

Settlement:

$$
\begin{aligned}
& \text { P = L: }(\text { i x n }) \\
& =25:(0.05 \times 1 / 7) \\
& =25: 0.0071 \\
& =3.5121 .12
\end{aligned}
$$

So, the amount that the government has invested is $3,5121.12$

\section{Covid-19 relationship in the political sector to compound interest (present value)}

From the data, the local government issued a budget to help people affected by Covid-19, the government disbursed 20 million per week for 1 month. Plus, the people who died will be given a caesarean 25 / person so that in economics and finances we will use calculations. Present value (PV) is also known as discount value. Now is the value of the expected income. Determine on the valuation date thus using the equation $\mathrm{PV}=\mathrm{FV}(1+\mathrm{C})$

The above data is known:

$$
\begin{aligned}
& \text { PV }=20 \text { million } \quad 1 \text { month }=4 \text { weeks } \\
& n=1 \text { month } \quad 1 \text { week }=20 \text { million } \\
& \mathrm{c}=0 \%=20 \times 4=80 \text { million per month } \\
& \text { asked FV ...? }
\end{aligned}
$$


Settlement:

$$
\begin{aligned}
& \mathrm{FV}=\mathrm{PV}(1+\mathrm{c})^{\wedge} \mathrm{n} \\
& =20(1+0)^{\wedge} \mathrm{n} \\
& =20 \times 1 \\
& =20 \text { million }
\end{aligned}
$$

So, the value of FV is 20 million while for government spending for 1 month it is 80 million.

\section{Conclusion}

The spread of the Corona Virus at first had a profound impact on the sluggish economic world, but it will also be felt by the world of education. The policies taken by many countries to carry out all educational activities have made the government and related institutions have to present alternatives as an educational process for students and students who cannot carry out the educational process in educational institutions. The spread of the corona virus (Covid-19) outbreak which is getting more and more ferocious is giving collective anxiety if it has been in the world for too long. Covid-19 will slowly lead countries to a potential crisis in a number of strategic lines so that it does not rule out the possibility of bringing the world to an economic crisis that result in a political crisis.

\section{References}

Baldwin, R., \& Weder di Mauro, B. (2020). Economics in the Time of COVID-19.

Bonoli, G. (2010). The political economy of active labor-market policy. Politics \& Society, $38(4), 435-457$.

Douglas, M., Katikireddi, S. V., Taulbut, M., McKee, M., \& McCartney, G. (2020). Mitigating the wider health effects of covid-19 pandemic response. Bmj, 369.

Clemens, J., \& Veuger, S. (2020). Implications of the COVID-19 Pandemic for State Government Tax Revenues (No. w27426). National Bureau of Economic Research.

McKibbin, W. J., \& Fernando, R. (2020). The global macroeconomic impacts of COVID-19: Seven scenarios.

Nicola, M., Alsafi, Z., Sohrabi, C., Kerwan, A., Al-Jabir, A., Iosifidis, C., ... \& Agha, R. (2020). The socio-economic implications of the coronavirus pandemic (COVID-19): A review. International journal of surgery (London, England), 78, 185.

Ramelli, S., \& Wagner, A. F. (2020). Feverish stock price reactions to covid-19.

Rosenbaum, L. (2020). Facing Covid-19 in Italy—ethics, logistics, and therapeutics on the epidemic's front line. New England Journal of Medicine, 382(20), 1873-1875. 